DOI: $10.17805 /$ zpu.2019.4.3

\title{
Научная школа МосГу по молодежным исследованиям: становление, состояние, перспективы
}

\author{
В. А. ЛУКОВ \\ МОСКОВСКИЙ ГУМАНИТАРНЫЙ УНИВЕРСИТЕТ
}

\begin{abstract}
В статье представлена научная школа Московского гуманитарного университета по молодежным исследованиям. Показано, что она возникла как итог переосмысления более ранних исследований молодежи в организациях, которые предшествовали университету. В период осуществления в 1987-1991 гг. на базе НИЦ реализовывался крупный научный проект, имеющий большое общественно-политическое значение, - готовился проект закона СССР «Об общих началах государственной молодежной политики в СССР». Это и позволило сформировать концептуальное понимание молодежи, молодежного движения, молодежной политики, что осуществил И. М. Ильинский в гуманитарной теории молодежи. Теория породила концепции «воспитания жизнеспособных поколений», «образовательной революции», “социализационной нормы» и др., обеспечивших развитие научной школы на следующих этапах. Соединение молодежной проблематики с тезаурусным подходом в рамках научной школы МосГУ дало продуктивные результаты.

В статье отмечается, что новое качество школе придаст активное изучение процессов, которые порождает в молодежной среде цифровизация.

Ключевые слова: научная школа; молодежь; Московский гуманитарный университет; гуманитарная теория молодежи И. М. Ильинского; Игорь Михайлович Ильинский; социализация; тезаурусный подход
\end{abstract}

\section{BВЕАЕНИЕ}

$\mathrm{M}$ осковский гуманитарный университет восходит в своей истории к Центральной комсомольской школе, начавшей работу в 1944 г., когда было ясно, что конец войны близок и Победа уже на горизонте, но впереди было восстановление разоренной фашистским нашествием страны, где от того, как в это дело включится молодежь, зависела стратегия развития СССР и стран, которые пошли за ним. Возникновение в 1969 г. Высшей комсомольской школы при ЦК ВАКСМ как вуза первой категории продолжило путь ЦКШ, и многие поколения комсомольских работников помнят и сегодня этот вуз, которому в этом году исполнилось полвека, как важнейшую часть своего становления и как образец реализации молодежи огромной державы в масштабных делах. Став в новых социально-экономических условиях Институтом молодежи, вуз даже в названии продолжил свою линию.

Эти факты хорошо известны, а развитие университета по оси ЦКШ - ВКШ - ИМ МГСА - МосГУ показано с разных сторон и основательно и по документам, и по оценкам роли руководителей вуза в разные годы, и по становлению новых для страны специальностей (первый в стране факультет рекламы, первый факультет социальной работы, один из первых факультетов культурологии), и по новаторским решениям (соединение сил передового гуманитарного вуза и Института психологии РАН в становлении факультета психологии, создание Русского интеллектуального клуба, научно-исследовательских центров биоэтики, русских исследований, а позже - Шекспировского центра) в многочисленных книгах и статьях (Васильев, Мухамеджанов, 2008; Возвращаясь ... , 2009; Ильинский, 2009, 2011; Ректор ... , 2013; Ручкин, 2011).

В определенном смысле можно в этих событиях видеть источник (в одних), результаты (в других) и зону становления и развития (в третьих) научных ориентиров, на ко- 
торые опирался МосГУ с момента создания своих предшественников. Надо определенно сказать, что молодежный уклон в этих ориентирах предопределен тем, что уже 75 лет вуз связан - сначала непосредственно, а потом по традиции - с формированием кадровой базы для молодежного организованного движения, для сферы государственной молодежной политики. Итак, молодежный уклон объективно определен этими внешними обстоятельствами. Но он вовсе не предполагает научной школы. Он вполне может осуществляться на базе того, что уже сделано в исследовательском плане другими, не содержать ни новых идей, ни новых подходов, ни связи в научном сообществе поколений исследователей, каждое из которых способно научиться существенному в изучении и понимании предмета своего знания у предшественников и развить на этой основе новое знание, которое способно передать следующим за ними поколениям ученых. Характерно, что с 1962 г. в Костроме, Новосибирске, Челябинске, Воронеже, Курске и других городах в педвузах в советское время возникли отделения, а потом историко-педагогические факультеты, предусматривавшие специализированную подготовку методистов пионерской работы (Басов, Кирпичник, Рассадин, 2007: 97), в 2003 г. была введена специальность «Организация работы с молодежью» (приказ от 12 августа 2003 г. № 3310 Министерства образования и науки РФ), в 2004 г. было сформировано УМО по этому профилю на базе МГУ им. М. В. Аомоносова (при этом уже была специализация «Социальная работа с молодежью» в рамках специальности 040101.65 «Социальная работа»), но научных школ молодежных исследований вокруг вузов с такими направлениями подготовки не сложилось.

Следовательно, тематическая связь функций организации с предметом исследования хоть и важна как непосредственный повод к формированию соответствующей научной школы, хоть дает научно значимые результаты и даже порождает научные школы, но другие, т. е. в другой области (как в случае с Костромским пединститутом работы $\Lambda$. И. Аутошкина и А. Н. Уманского стали основой научной школы в области психологии и педагогики социального воспитания, но не основой теории детского общественного объединения, как следовало из их работы на «пионерфаке», см.: Уманский, Аутошкин, 1984). А что же надо считать существенным?

Эта сторона становления и развития научных школ и рассматривается в данной статье.

\section{НАУЧНАЯ ШКОАА - СМЫСА ТЕРМИНА}

Повсеместно упоминаемая трактовка динамики науки в связи с концепцией смены научных парадигм, выдвинутая Т. Куном (Кун, 2001), довольно редко предусматривает его понимание научных школ как предпарадигмальных форм науки, когда налицо борьба научных школ. Кун отказался от этой идеи, предполагающей, помимо прочего, что с утверждением парадигмы роль научных школ сходит на нет. Отказ означает признание, что при смене парадигм снова возрождаются научные школы. Но это лишь одна сторона значимости научных школ в науке. Она, в частности, совсем не учитывает пути и объем коммуникаций в научных сообществах, которые в одних случаях нуждаются в максимальной доступности новых идей (так появляются аннотации статей, активное владение «мировым» языком, которым в одно время была латынь, позже, в XVIII - начале XIX в., - французский, а сейчас - английский), а в других - в закрытости сообществ, недоступности знаний для непосвященных, даже когда им известен язык публикаций, когда это родной язык, но текст непонятен (такие феномены имеются в философии, лингвистике и других сферах знания). 
В давнишнем (еще 1995 г.) симпозиуме о судьбах социологии в России (а дискуссия собрала видных российских социологов) академик РАН Т. И. Заславская заметила в характеристике новосибирской социологической школы: «Если иметь в виду иерархизированное и самовоспроизводящееся научное сообщество, внесшее крупный вклад в мировую науку, то таких школ не было ни в регионах, ни в Москве. Под школой можно понимать и сообщество, занимающее определенную нишу в отечественной науке, воспроизводящее себя в новых поколениях специалистов и отличающееся определенной методологией. Такая школа в Новосибирске была» (Социология ... , 1995: 63). Собственно, два смысла научной школы хорошо представлены в этих словах. Но их отличие, по существу, «географическое»: в первом случае на передний план выдвигается «мировая наука», во втором - «отечественная наука».

В естественно-научных исследованиях ориентация на «мировую науку» совершенно необходима, а научная школа только тогда имеет основание для выделения, когда соответствует трендам «мировой науки». Например, в сфере генетики СССР был оАним из источников передовых идей и ориентиров до сессии ВАСХНИА в 1948 г., известной своим разгромом «вейсманистов-морганистов», последствием чего стали запрет генетики и катастрофическое отставание страны, а значит, соответствующих научных сообществ, талантливых ученых, научных институтов от «мировой науки». Много позже в определенных зонах генетики отставание было сокращено, но все же для выделения научных школ мировые достижения являются надежным ориентиром. Так, для генного редактирования в 2017 г. были доступны 9 редакторов генома 1 , и соответствующие научные сообщества России могут двигать генетику вперед, если их разработки исходят из достигнутого мирового уровня.

Однако для гуманитарных и социальных наук первое понимание («мировая наука») оказывается абстракцией и сбивающим с толку обобщением. Еще в Баденской школе неокантианства (конец XIX - начало XX в.) было показано, что науки о духе (в нынешней интерпретации - науки о культуре) строятся на иной основе, чем естественно-научные знания (науки о природе): они выявляют не общее как итог научного знания, а значимое для человека, т. е. их выводы, обобщения, типологизации и т. А. группируются вокруг ценностей. Этот вывод В. Виндельбанда, а потом Г. Риккерта остается современным и сейчас (Иуков, 2017: Электронный ресурс). Если из него исходить, то термин «мировая наука» не должен применяться в отношении ценностноориентированных наук, не могут в этом аспекте сопоставимый (тем более «передовой», служащий как ориентир для других) вклад в «мировую науку» вносить Китай и Аатинская Америка, Европа и Россия.

А тогда остается общее понимание научной школы как научного сообщества, связанного определенной идеей. Иначе говоря, называя нечто «сообществом», мы сразу признаем, что оно иерархизировано, и основа такой иерархии - ось «учитель - ученик». Мы также признаем, что оно самовоспроизводящееся, точнее - саморазвивающееся, что ему присущ закон преемственности и смены поколений. Когда мы говорим об идейной связи, то сюда относится не только методология, но и концепция определенной сферы жизни человека. Вот почему общий предмет исследований важен, но недостаточен для научной школы: если нет объединяющей концепции предметной области, то нет и базы для образования сообщества, а есть лишь трудно соединимые его осколки.

При таком понимании теряет смысл и привязка данного научного сообщества к «определенной нише» в науке. Ниша (если не исходить из понятий архитектуры) 
обычно связывается с ограниченной чем-то сферой деятельности. Вряд ли здесь применима ограниченность географическая - страна, регион и т. д. В Бельгии в 2019 г. население составляло 11,48 млн человек, в России - 146,56 млн. Та и другая - страны. Но в Москве в то же время проживали 12,62 млн, т. е. больше, чем в Бельгии². Означает ли это, что исследования по населению Бельгии относятся к общеевропейским, а по населению Москвы - к региональным или местным?

То же касается и групп жителей: «ниши» здесь ничего не проясняют, а концепции, относящиеся к прошлому, настоящему и будущему человека, общества, культуры, позволяют увидеть «нить времен» и приемлемы и для больших социальных общностей, и для малых, поддерживая подход к равной ценности культур разных народов.

Как и во всей истории науки, становление научной школы сочетает устойчивые, институционализированные черты и черты случайные, возникающие под воздействием конкретных обстоятельств, нередко очень далеких от конечного результата, и в момент появления никак не связанные с тем, что потом признается «научной школой».

Первый круг обозначается довольно четко и считается признаками научной школы: «...коллектив исследователей, удовлетворяющий следующим критериям: 1) наличие научного лидера, конструктора новой исследовательской программы; 2) наличие "учеников", последователей, приверженцев созданной лидером научно-исследовательской программы (объединенных либо в формальную научную группу, либо в “невидимый” колледж); 3) воспроизводство нескольких поколений (не менее 3) приверженцев данной программы; 4) эффективность программы, подтвержденная деятельностью ее приверженцев» (Иебедев, 2011: 110). Придерживаясь этой позиции, Н. А. Селиванова отмечает: «Аругое мнение по поводу того, что есть научная школа, представляет собой практически прямо противоположную позицию, когда научной школой фактически считается сообщество ученых, созданное для реализации какоголибо проекта. Поэтому встречаются “научные школы”, которые уже в момент создания именуют себя таковыми» (Селиванова, 2018: 12).

По сути, и первая (Аебедев и др.), и вторая (отмеченная Селивановой) черты соотносятся с институционализацией научной школы, поскольку исследовательскую задачу ставит перед ней внешний институт. Эту задачу можно выполнить в пределах уже принятых научных норм, но важно, что она стоит и не может быть разрешена на уровне здравого смысла, т. е. предполагает исследование (хотя бы важное как убеждающий «других» аргумент в пользу принятого «своими» решения и без предварительного изучения темы), иначе не могла бы быть поставлена.

Есть и другая сторона устойчивости научных школ: в этом случае под ними понимается подготовка следующих поколений ученых. Такой подход реализован в постановлении Правительства Российской Федерации от 27 апреля 2005 г. № 260 «О мерах по государственной поддержке молодых российских ученых - кандидатов наук и докторов наук и ведущих научных школ Российской Федерации». В соответствии с этим постановлением уже много лет («устойчиво») выделяются гранты Президента Российской Федерации для государственной поддержки ведущих научных школ Российской Федерации. В новейших документах подчеркнуто: «В 2020 году будут поддержаны научные школы, которые отвечают следующим условиям: возраст руководителя на 1 января 2020 года не превышает 50 лет; за период 2015-2019 гг. руководителем научной школы подготовлено (подтверждено дипломом ВАК) минимум 3 кандидата и (или) доктора наук»3․ В этой связи дается правовое определение: «Ведущей научной 
школой Российской Федерации считается сложившийся коллектив исследователей различных возрастных групп и научной квалификации, связанных проведением исследований по общему научному направлению и объединенных совместной научной деятельностью, руководители которых на регулярной основе осуществляют подготовку кандидатов и докторов наук, тем самым формируя исследовательские группы, обеспечивающие развитие и рост результативности российской науки» 4 .

Очевидно, что и в этом случае гранты ориентированы на структурные элементы, присущие научным школам независимо от того, в какой сфере они формируются.

Каковы же случайные черты, ведущие к образованию, становлению и развитию научных школ? Что это за конкретные обстоятельства, далекие от того, что потом, нередко много лет спустя, будет названо и признано «научной школой»?

В плане тематики исследований импульс к формированию научных школ дает новая проблемная ситуация в условиях, когда ранее принятые теории и методы дают неточные или неверные результаты, т. е. не те, которые отвечают общественным ожиданиям. Неточность или неверность итогов исследований в социальных и гуманитарных науках обычно не связаны с низкой квалификацией исследователей. Это именно ценностная реакция на то, что получилось, даже если были применены самые проверенные способы анализа, до того показывавшие свою высокую надежность.

Таково, в частности, исследование конца 1960-х гг. по университетской молодежи в США маркетинговой и исследовательской фирмы Daniel Yankelovich Inc. В недавних статьях, описывающих это исследование на основе вторичного пересказа (Маркина, Твирова, Шумилова, 2010, 2014), не учитываются некоторые важные детали. А. Янкелович - один из наиболее признанных в США исследователей общественного мнения, что еще раз было подчеркнуто в некрологах 2017 г. ${ }^{5}$ Его квалификация как социолога определяется и тем, что он окончил Гарвард и Сорбонну, а также тем, что созданная им в 1958 г. частная фирма к моменту исследования процессов в студенческой среде уже более 10 лет успешно вела исследования, хотя «большую часть послевоенного времени два исследовательских центра и их продукция задавали тон в исследовании американского, а затем и международного общественного мнения - The Galup Poll и The Harris Poll» (Попов, 2017: 299). Надо учитывать и то, что в специальном трехчасовом телевизионном выпуске CBS 1969 г. «Разделенные поколения», основу которого составили исследования американской молодежи, проведенные фирмой Янкеловича, впервые было показано, что в Америке назрел «разрыв поколений». Имевшая большую популярность и сделавшая имя Янкеловичу, эта передача была тогда же представлена в книге (Yankelovich, 1969), которая появилась раньше, чем обобщения «конфликта поколений» Маргарет Мид и других авторов. Подкрепленные эмпирикой, обобщения Янкеловича были восприняты в общественном мнении как объяснительная схема (Jennings, Niemi, 1975).

Иначе говоря, проблема не в том, что Янкелович проглядел ситуацию в американских университетах (как и Харрис), он довольно рано сумел ее обобщить, а в том, что количественная стратегия в социологии не выявляла то, что было заметно на уровне интуиции многим, а именно то, что ситуация менялась на глазах и напоминала ядерную реакцию, которая, начавшись, была неостановима.

Аля социологии это означало кризис принятых ранее правил и представлений о научности и требовало искать новые способы понять реальность, что определило не только проблемную ситуацию в странах Запада, но и в СССР, Болгарии, ГАР, Польше, Румынии, Чехословакии, где появились особые структуры (институты, центры), 
специально занимавшиеся молодежной проблематикой, но и - спустя некоторое время - новые теории молодежи, ставшие основой научных школ.

Вторая непланируемая черта научной школы - характер ее руководителя. Субъект, формирующий научную задачу (орган, организация, личность, наделенная соответствующими правами), может, конечно, решать кадровые вопросы при создании некой научной структуры, но это решение может и не приводить к созданию научной школы, хотя бы и все формальности были соблюдены. Руководитель может быть жестким, его могут бояться сотрудники. Он может быть мягким, нетребовательным, не способным обострять отношения. Он может быть лучше готовым выполнить любую технологическую функцию, чем кто-либо из его подчиненных, а картина бывает и прямо противоположная. От этого многое зависит в организации, но не научная школа. Аля того чтобы школа появилась в социальной и гуманитарной областях (т. е. там, где основу научного знания составляет система ценностей), нужно особое качество руководителя - концептуализм, за которым следует расширение горизонтов знания. Если нет этого качества, то нет и школы в гуманитарной области.

Поразительный пример показывал Роберт Парк, возглавлявший Чикагскую социологическую школу в 1915-1934 гг. На фоне видных мыслителей, собранных этим частным университетом (среди них У. Томас, Аж. Г. Мид, Аж. Аьюи и др.), Парк не остается в тени, его и его идеи принимают и молодые ученые, и студенты, он не боится тех и других включать в социальные исследования, так нужные для городских властей, когда Чикаго вырос из небольшого поселка за очень короткое время и еще неустойчив в своих связях, наполнен шайками преступников, неуправляем. Во многом качества личности Парка предопределили его положение неформального лидера школы: он легко рождал новые идеи и охотно делился ими с учениками. Он не боялся, что у него что-то «украдут», ему нетрудно было придумать новое, которое возникает на перекрестке наук. Мастерство комбинаций и есть концептуализм.

Наконец, важно увидеть в «учениках» продолжателей школы по ее идеям, причем в расширенном понимании, т. е. в их развитии применительно к разным сферам науки (отраслям науки в том числе). Формальный подсчет защищенных докторских и кандидатских диссертаций для условий конкурса применим, поскольку упрощает подсчеты, но скорее затемняет специфику научной школы, чем проясняет ее. В гуманитарных и социальных науках движение от общих теорий руководителя (руководителей) к их конкретизации и введению новых идей учениками наиболее продуктивно на полях междисциплинарности и трансдисциплинарности (Трансдисциплинарность ... , 2015).

\section{СТАНОВАЕНИЕ НАУЧНОЙ ШКОАЫ В МОСГУ: РОЖАЕНИЕ ОБЪЕАИНЯЮЩЕЙ ИАЕИ}

Научная школа Московского гуманитарного университета по молодежной проблематике возникла как итог переосмысления более ранних исследований молодежи в организациях, которые предшествовали университету. Ааборатория конкретных социологических исследований ВКШ с начала 1970-х гг. (В. А. Смирнов, В. И. Мухачев и др.) вела исследования только на молодежном сегменте населения, опираясь на технологии, которые тогда были доступны (компьютерной обработки данных в современном смысле не было, и в эмпирических исследованиях в лаборатории, как и во всех социологических подразделениях, применялись перфокарты; ЭВМ требовали программистов со специальной подготовкой, исследователь ставил перед ними ограни- 
ченный круг задач, не имея возможности менять их в рамках исследования). В теории также не приветствовались новые идеи, и наращивание данных анкетных опросов было фактически главным результатом многих исследований в молодежной среде. Показательно в этом плане первое крупное социологическое исследование, проведенное на базе ВКШ, «Формирование достойной смены рабочего класса и колхозного крестьянства», где анкеты издавались целой книгой, содержавшей около 100 страниц.

Создание на базе ряда научно-исследовательских подразделений Научно-исследовательского центра ВКШ в 1976 г. означало продвижение в институциализации молодежных исследований, здесь работали ученые, впоследствии внесшие заметный вклад в социологию молодежи, сформировавшие новые тематические поля в молодежных исследованиях (комсомольское строительство, выступавшее как инвариант теории молодежной организации, международное молодежное движение - инвариант теории молодежного движения, история ВАКСМ и др.). Тем не менее эти работы (а в начале 1980-х годов в НИЦ работали около 200 научных сотрудников) еще были преддверием научной школы, но не самой школой, поскольку многочисленные собственные исследования и выдвижение НИЦ на передний план в координации молодежных исследований в стране не порождали оригинальной теоретической основы для сближения всей исследовательской работы коллектива, отделы НИЦ были связаны разве что тематикой, но не признанной в этой организации концепцией - «идеей», которая проводилась бы через многообразие научной работы.

Выдвижение И. М. Ильинским, директором НИЦ в 1984-1994 гг., гуманитарной концепции молодежи многими сотрудниками этой научной организации не было воспринято как новация, требование обновления концептуальной опоры. В уже устоявшемся научном организме по-прежнему выстраивались планы работы, велись исследования по частным темам. По этому поводу И. М. Ильинский отмечал на научнопрактической конференции «Наука о молодежи - 85»: «...в борьбе за практическую значимость исследований, за более тесные связи с практикой нас подстерегает опасность, которой необходимо избежать: это узкий практицизм, замыкающийся на будничной текучке... Аа, безусловно необходимы рекомендации комитетам комсомола Аля непосредственного использования их в работе. Аа, необходимы учебные пособия, учебники и методики для учебного процесса в районных школах комсомольского актива, для педагогических вузов. Все это - практика. Но кроме того, есть еще и практика научного познания, т. е. работа науки для науки, на цели и задачи собственного развития - обращение к своим основаниям, разработка категориального аппарата и т. д. Забыть это - значит нанести ущерб не только темпам развития системы научных знаний о молодежи и комсомоле, но и, в конце концов, их практической приложимости» (Ильинский, 1986: 39).

Значение обобщающей концепции молодежи стало ясно в период осуществления в 1987-1991 гг. на базе НИЦ крупного научного проекта, имеющего большое общественно-политическое значение, - подготовки проекта закона СССР «Об общих началах государственной молодежной политики в СССР», а позже и связанных с ним по идеям, содержанию и механизмам Федерального закона «О государственной поддержке молодежных и детских общественных объединений» (1995), Федерального закона «Об основных гарантиях прав ребенка в Российской Федерации» (1998), подготовки других нормативных правовых документов федерального и регионального уровней, а также государственных докладов о положении молодежи в Российской Федерации, которые были опубликованы в 1993, 1995, 1996, 1998, 2000, 2002 гг. Все это 
время НИЦ вел мониторинговые исследования «Молодежь России» по общероссийской выборке (по заказу государственных органов).

В чем суть гуманитарной концепции молодежи И. М. Ильинского? В обобщающей монографии о научной школе МосГУ (Ковалева, Ауков, Перинская, 2016) она изложена в восьми базовых положениях.

1. Молодежь - это объективное общественное явление, выступающее всегда как большая специфическая возрастная подгруппа. Ключом к познанию природы молодежи является диалектика целого и части («молодежь - часть общества; молодежь часть общества»). Специфические, обусловленные возрастом проблемы молодежи в любом обществе состоят в том, что (а) молодость тесно связана с идеей зависимости; (б) большая часть молодежи (учащиеся, студенты и т. п.) еще не включена в процесс производства и потому «живет в кредит»; (в) большинство молодых людей не обладает личной самостоятельностью в принятии решений, касающихся их жизни; (г) перед молодыми людьми стоит проблема выбора сферы трудовой деятельности, выбора профессии; (д) молодые люди решают проблему нравственного и духовного самоопределения; (е) они решают проблему брачного выбора и деторождения.

2. Молодежь по природе двойственна: она - явление биологическое и сочиальное, что определяет связь ее психофизического и социального развития.

3. Молодежь - явление конкретно-историческое. Это означает, что «число определений молодежи может быть равно числу конкретных обществ, каждое из которых выводится из общего определения молодежи и в то же время служит базой для конкретизации этого определения».

4. Молодежь - это носитель огромного интеллектуального потенциала, особых способностей к твориеству.

5. Молодежь одновременно объект и субъект соииализаиии, что определяет ее социальный статус.

6. Молодежь обретает субъектность по мере самоидентификации, самоосознания своих интересов, роста своей организованности.

7. Молодежь - носитель процессов, которые развернутся в полную мощь в будущем.

8. Молодежь - объект комплексных, междисциплинарных исследований, которые только в своей совокупности могут дать достаточно достоверную картину о ней.

Эти положения, последовательно изложенные И. М. Ильинским в монографии 2001 г. (Ильинский, 2001: 108-120), для времени их выдвижения были во многом дискуссионны. В частности, еще на международных симпозиумах в Приморско (Болгария), проходивших по молодежной проблематике с 1970 г. (Международные ... , 1987), понятие «социализация» осуждалось, а частью и высмеивалось как буржуазный суррогат «коммунистического воспитания». Аля многих непонятна была и субъектность молодежи (часто приравниваемая к ее субъективности и потому критикуемая как неприемлемая для объективной науки об обществе).

Между тем идея субъектности молодежи (иногда в другом понятийном облачении) поставлена в центр концепции И. М. Ильинского: в стремительно меняющемся мире необходимо опереться на субъектность молодежи, чтобы вытянуть иелое - все общество, его настоящее и будущее. Это концептуальное переосмысление роли молодежи и молодежного движения в новых социальных и культурных условиях позже стало осмысляться на фоне обострения глобальных мировых проблем и повсеместных социокультурных инноваций (Ковалева, Ауков, 1999; Ауков, 2006, 2007, 2013а, 2014). 
Концепция Ильинского породила его обобщения в смежных областях знания: в 1995 г. он выдвинул концепцию воспитания жизнеспособных поколений в связи с пониманием роли воспитания как общероссийской задачи. Жизнеспособность, по Ильинскому, - это «способность человека (поколения) выжить, не деградируя, в “жестких" и ухудшающихся условиях социальной и природной среды, развиться и духовно возвыситься, воспроизвести и воспитать потомство, не менее жизнеспособное в биологическом и социальном планах» (Молодежь России ..., 1995: 224). Отсюда проистекает задача жизнеспособной дичности - стать индивидуальностью, сформировать свои смысложизненные установки, самоутвердиться, реализовать свои задатки и творческие возможности, преобразуя при этом в своих интересах среду обитания, не разрушая и не уничтожая ее. Включенная как приложение к государственному докладу, подготовленному под руководством И. М. Ильинского, эта концепция, как и весь доклад, была отвергнута тогдашним правительством Российской Федерации и вновь стала актуальна на федеральном уровне через 20 лет (на региональном уровне она в эти годы многократно принималась за образец при выработке соответствующих решений).

Из гуманитарной концепции молодежи берет свое начало и концепция молодежной политики, которая И. М. Ильинским определена как «способ регулирования межпоколенческих отношений, управления прочессом преемственности поколений u, стало быть, развития общества» (Ильинский, 2001: 579). Позже И. М. Ильинский подчеркивал: «Молодежная политика - это центральное звено политики национальной безопасности, берущей начало в настоящем и обращенной - от поколения к поколению - в далекое будущее» (Ильинский, 2005: 13).

Концепция образовательной революции (Ильинский, 2002а, 2010) тоже происходит из гуманитарной концепции молодежи. Ведущими в концепции становятся, вопервых, утверждение о том, что конечная цель образования - понимание, и, во-вторых, тезис об особой роли высшей школы в разрешении кризиса понимания, сформировавшегося в современную эпоху. Тема кризиса понимания многократно и детально рассматривается И. М. Ильинским (Ильинский, 2002b).

Все же исходной является первоначальная концепция. Здесь уместна аналогия с представлением диалектики становления у виднейшего русского философа А. Ф. Аосева. Он писал: «Становление есть такая смена одного момента другим, когда каждый отдельный момент при своем возникновении тут же и уничтожается, снимается. Подлинное становление - это та область, для которой существенна именно эта непрерывная текучесть и изменчивость вещей и явлений... Зерно или семя растения еще не есть само растение, хотя и содержит его в себе в неразвернутом виде. И само растение еще не есть ни его расцвет, ни его гибель, ни его ствол, дистья и цветы, хотя все это уже содержится в семени или зерне в неразвернутом виде. Поэтому категория становления, т. е. становление, продуманное до конца, является, в сущности говоря, не только непрерывной эволюцией, но и прерывными революционными скачками. Всякая линия становления, которая в первую очередь мыслится эволюционно, обязательно оснащена тем или иным количеством скачков, отнюдь не мешающих непрерывному становлению, а только демонстрирующих разные его типы, революционно возникающие в результате самого же становления» (Иосев, 1977: 3-4).

В лосевском смысле и нужно рассматривать применительно к становлению, состоянию и перспективам научной школы молодежных исследований МосГУ гуманитарную концепцию молодежи И. М. Ильинского. 
«РАЗВЕТВАЕНИЕ» ШКОАЫ

Научные школы - живой общественный организм, они рождаются и развиваются, уходят из общественной памяти совершенно так же, как другие живые организмы, не поддерживаемые искусственно, т. е. представляющие собой (в аспекте общественных образований) неформальные сообщества. В этом их отличие, например, от социальных институтов, сохраняемых шлейфом учреждений и формально закрепленных правил, от подобных же организаций. В этом качестве научные школы более уязвимы, зависят от непредвиденных обстоятельств, но через распространение на новые территории науки и, «ветвясь» по идеям и методам познания, способны довольно долго существовать. Преобразуясь, они не покидают исходной территории (тематики исследования). Это хорошо показала история гуманитарных и социальных наук.

Школа Аюркгейма, называемая сегодня Французской школой социологии, могла бы остаться только историческим фактом науки конца XIX - первой трети XX в., если бы принадлежавшие к ней М. Мосс, $\Lambda$. Аеви-Брюль, С. Бугле, М. Хальбвакс и другие не распространили дюркгеймовский «социологизм» на широкий круг наук о человеке и обществе, не высказали новые идеи в экономике, этнографии, лингвистике и т. А. (Leroux, 1998). Не случайно к этой школе относят антрополога К. Аеви-Стросса, психолога П. Жане и других по работам, а не по непосредственным контактам. Влияние Аюркгейма обнаруживают у П. Бурдьё, И. Гофмана, Р. Коллинза, а за пределами социологии - у М. Фуко, Э. Аевинаса, многих других ученых. Частью это свидетельство значительности трудов самого ученого, хотя уже М. Мосс, возглавивший школу после смерти Э. Аюркгейма в 1917 г., критиковал многие положения своего учителя, а дискуссия о ненадежности источников и выводов Аюркгейма продолжается и поныне (Searle, 1995, 2010; Gross, 2006). Но очевидна и долгая жизнь научной школы (до 1930 г. в ее непосредственном виде, но и в последующие годы - через публикации), сохранившей основу методов ее основателя и открывшей их применимость в смежных сферах науки.

«Разветвление» школы Ильинского шло по нескольким направлениям. Одно из них означало формирование нового взгляда на социализацию. Проблему составляло не только то, что долгое время само это понятие не признавалось в советских научных сообществах, но и то, что преодоление этого непризнания в отечественной науке шло главным образом в ключе социальной психологии и педагогики. Частью это было связано с тем, что положительная трактовка этого термина была дана в известной книге И. С. Кона «Социология личности» (Кон, 1967), где собственно социологической трактовки социализации и не было.

В ключе гуманитарной концепции молодежи И. М. Ильинского сформировалось понимание социализации именно как социологического феномена. Концепция социализационной нормы, разработанная А. И. Ковалевой, решила эту теоретическую задачу (Ковалева, 1997, 2017). Социализационная норма определяется Ковалевой, во-первых, как результат успешной социализации, позволяющей индивидам воспроизводить социальные связи, общественные отношения и культурные ценности данного общества и обеспечивать их дальнейшее развитие; во-вторых, как многомерный эталон социализированности человека с учетом его возрастных и индивидуальнопсихологических характеристик; в-третьих, как устоявшаяся в обществе совокупность правил передачи социальных норм и культурных ценностей от поколения к поколению (Ковалева, 1997: 7-8). Связь с социологией определялась в этом «разветвлении» гуманитарной концепции молодежи тем, что социализационная норма ос- 
мыслялась как мера социализированности индивида в соответствии с характеристиками социальности данного общества. Выделение социализационной нормы оказалось продуктивным для исследования детей и молодежи, поскольку именно она (а не общая социальная норма) выстраивает каркас социального статуса человека в период детства и юности. Она оказалась продуктивной и в вопросах, которые почти не рассматривались отечественной социологией, например, при выявлении особенностей социального статуса молодых людей с ограниченными возможностями - имеющих отклонения в физическом и умственном развитии, неслышащих и др. (Ковалева, Реут, 2001; Жулковска, Ковалева, Ауков, 2003).

Это направление «разветвления» укрепилось также формированием концепции социализационной траектории (Ковалева, Богданова, 2012). В итоге социализационная линия обогатила теоретические основы школы молодежных исследований МосГУ.

Аругое направление «разветвления» видится в усилении социокультурного аспекта субъектности молодежи (Ауков, 2019). Оно состоит в том, что социокультурная субъектность молодежи рассматривается как основное приобретаемое ею социальное и культурное свойство, преодоление неполноты которого составляет суть ее самореализации в обществе и отношения других возрастных групп к ней. В этом ракурсе показано, что «свое-чужое-чуждое» как первоэлементы тезауруса «отличаются в молодежной среде и могут быть изучены социологией культуры через анализ ценностных ориентаций, идентичностей и инновационной активности молодежи, включая прежде всего коллективные формы молодежного движения (организации, субкультуры, солидарности). Социальная субъектность и генетически, и системно не может быть выявлена и интерпретирована вне ее объективных оснований - социально-экономических, культурных, политических условий, образа и стиля жизни, ценностнонормативной системы и др. Эти объективные основания выступают как рамка достижимого уровня субъектности, в том числе и применительно к молодежи» (там же: 13).

Здесь, с одной стороны, развивается важная идея социальной субъектности, изучавшаяся в НИЦ с 1980-х гг. и вошедшая в гуманитарную концепцию молодежи И. М. Ильинского, а с другой - находит зону своего применения тезаурусный подход к социальным и культурным явлениям, который как общеметодологическая концепция был разработан в МосГУ при обосновании оригинальных теоретических концепций молодежи, социализации, социального проектирования (Ауков В. А., Ауков Вл. А., $2008,2013,2014)$, а также в таких областях социальных и гуманитарных наук, как шекспироведение (Захаров, 2008; Гайдин, 2011), тувиноведение (Аамажаа, 2012), культурология (Костина, 2008). Тезаурусный подход был применен как теоретико-методологическое основание в работах докторантов и аспирантов МосГУ А. А. Аграната, М. В. Вдовиной, Н. А. Завьяловой, И. Г. Биченко, М. Вальдес Одриосола, В. В. Воробьева, А. В. Аоскальчука, М. Я. Курганской, А. В. Аукова, С. В. Аукова, Ю. Е. Надточия, Э. К. Погорского, А. Г. Русановой, А. А. Ситникова, А. А. Тихомирова, Е. А. Туринцевой и др.

В начале 2010-х гг., основываясь на гуманитарной концепции молодежи И. М. Ильинского, концепциях социализационной нормы и социализационной траектории А. И. Ковалевой и на базе формировавшейся тезаурусной концепции молодежи, появилась концепция биосоциологии молодежи, которая наиболее полно была представлена в монографии «Биосоциология молодежи: теоретико-методологические основания» (Ауков, 2013b). 
Под биосоциологией здесь понимается научная концепция междисциплинарного характера, исходящая из неразрывной связи биологического и социального компонентов в жизни человека и человеческих сообществ (социальных общностей) и имеющая своим предметом те стороны социальной жизни, которые и на макроуровне, и на микроуровне человеческих взаимодействий непосредственно вытекают из биологической природы человека. Это в первую очередь вопросы гендера, возрастных различий, этнокультурной специфики, а также вопросы взаимодействия человека и человечества с искусственным миром, созданным ими и отчужденными от себя. Из этого, в частности, следует, что место биосоциологии в современном гуманитарном знании определяется по той же модели, какая закрепилась в биоэтике. На основе теоретикометодологической концепции биосоциологии могут быть выявлены и осмыслены возможные трансформации общества через накопление критической массы биологических и интеллектуальных (под воздействием факторов внешней среды обитания и вызванных искусственными средствами), а также социокультурных изменений в новых поколениях, что позволит также спрогнозировать с применением гуманитарной экспертизы изменения статуса-роли молодежи в обществе.

Таким образом, исследования в области биосоциологии молодежи продолжают линию, сформировавшуюся в научной школе молодежных исследований МосГУ, а их теоретическая основа имеет характер «разветвления» гуманистической теории молодежи И. М. Ильинского.

\section{ПЕРСПЕКТИВЫ ШКОАЫ}

Если исключить из числа факторов жизни научных школ внешние обстоятельства, к каковым могут быть отнесены крупные исторические события (войны, революции, массовые миграции и т. А.), перемены в мировоззрении критической массы народов (смена религии, ценностные ориентации на те или иные идеологии), а также и события меньшего размаха, но важные для научных коллективов (принятие новых законов, постановка благосостояния и общественного признания ученых от установленных органами государственной власти критериев научной продуктивности и др.), то в таком очищенном виде научные школы во времени развиваются подобно синусоиде, т. е. графически представляются как объекты с периодически волнообразным изменением. Математический смысл синусоиды (синус изменяющегося угла) здесь вряд ли приемлем, а волнистая линия, воспринимаемая как чередование подъемов и спадов, наглядно показывает, что научная школа не развивается линейно - от прогресса к еще большему прогрессу.

Однако в гуманитарной и социальной сферах науки не только нельзя уйти от внешних обстоятельств, поскольку они созданы людьми и неизменно несут на себе ценностные приоритеты, но необходимо исходить из того, что изучаемая такими науками часть реальности заведомо изменяется. Меняется, конечно, и вселенная, и солнце, и молекулы, и атомы, собственно, все объекты естественных наук, поэтому нельзя сказать, что меняются только методы исследования, а объекты неподвижны и принадлежат вечности. Но изменения в гуманитарной и социальной сферах происходят несравненно быстрее, при сочетании противоречивых тенденций, не могут быть по большей части заранее спрогнозированы. В силу этого перемены в научных школах не связаны только с развитием науки как таковой, но прежде всего определяются быстрыми и нередко краткосрочными переменами в самом изучаемом объекте, возвратами отвергнутого и неожиданными разрывами с традицией, переоценкой ценностей. 
Научная школа молодежных исследований МосГУ достигала особых своих подъемов примерно через каждые 10 лет, и в настоящее время есть предпосылки к началу нового подъема. Но циклы сами по себе не образуются, требуют управленческих усилий. В перспективе школа должна скорректировать и свою концептуальную основу, и эмпирические исследования с учетом приближения цифрового общества, распространением новых информационных коммуникаций, изменений в природных свойствах человека. То, что молодежь сегодня не та, что была 30-40 лет назад, ясно любому внешнему наблюдателю. Но от интуитивного приговора «молодежь не та» к научному выявлению новых и сохраняющихся черт «не той» молодежи лежит трудный путь, который заново раскроет потенциал научных школ, в том числе и сложившейся в Московском гуманитарном университете.

\section{ЗАКАЮЧЕНИЕ}

Научная школа возникла как итог теоретического осмысления материалов обширных и систематических исследований проблем молодежи. Ее основу составляют теоретические концепции молодежи, молодежной политики, молодежного движения, социализации. «Зерном» этих концепций стала гуманистическая теория молодежи И. М. Ильинского. Сегодня во многих положениях этой теории новые поколения исследователей не замечают следов идейно-теоретической борьбы прошлых лет, значимости этой теории для объединения большого отряда ученых, изучавших молодежный сегмент советского, потом российского общества. Тем важнее подчеркнуть, что такие крупные общенациональные задачи, как выдвижение концепции государственной молодежной политики, подготовка проекта закона СССР «Об общих началах государственной молодежной политики в СССР», на базе которого и был принят этот проект, а потом стал моделью для всего законодательства о молодежи в России, российских регионах, в постсоветских странах, не были бы реализованы вне соответствующей теории молодежи. Параллельно шел процесс формирования научной школы на месте, где молодежная проблематика сама по себе не могла бы породить что-то большее, чем серию эмпирических исследований.

«Разветвление» школы расширило тематику теоретических работ и их подтверждений в эмпирических исследованиях, охватывая как сферы молодежи, молодежного движения, молодежной политики, так и области высшего образования, социологии детства, социального проектирования, гуманитарной экспертизы и т. А. Через применение тезаурусного подхода, развитие которого тесно связано с МосГУ и школой молодежных исследований, ее «разветвление» утвердилось в культурологии и литературоведении, этнологии и социальной философии.

Новое качество школе придаст активное изучение процессов, которые порождает в молодежной среде цифровизация. Человеческий аспект этого процесса, как и социальные и культурные практики вовлечения молодежи в формирование своего будущего, которое может пойти не по начертанным планам создания нового общества, ждут новых поколений исследователей, опирающихся на достижения признанных научными сообществами научных школ.

ПРИМЕЧАНИЯ

1 Genome editing [Электронный ресурс] // Wikipedia. URL: https://en.wikipedia.org/wiki/ Genome_editing (дата обращения: 04.09.2019).

${ }^{2}$ URLE: https://countrymeters.info/ru/Belgium; https://countrymeters.info/ru/Russian_Federation 
3 Стартует конкурс на получение грантов Президента РФ для поддержки научных школ (2019) [Электронный ресурс]. URL: https://minobrnauki.gov.ru/ru/press-center/card/?id_4=1959 (дата обращения: 04.09.2019).

${ }^{4}$ Там же.

5 McFadden R. D. (2017) Daniel Yankelovich, Master of Public Opinion Research, Dies at 92 [Электронный ресурс]// New York Times. September 22. URL: https://www.nytimes.com/2017/09/22/ business/daniel-yankelovich-master-of-public-opinion-research-dies-at-92.html (дата обращения: 04.09.2019).

\section{СПИСОК АИТЕРАТУРЫ}

Басов, Н. Ф., Кирпичник, А. Г, Рассадин, Н. М. (2007) Феномен пионерфака (к 45-летию историко-педагогического факультета КГПИ) // Вестник Костромского государственного университета. Педагогика. Психология. Социальная работа. Акмеология. Ювенология. Социокинетика. № 1. С. 97-102.

Васильев, Ю. А., Мухамеджанов, М. М. (2008) Центральная комсомольская школа : ист. очерк / рук. науч. проекта И. М. Ильинский ; отв. ред. А. А. Королев. М. : Изд-во Моск. гуманит. ун-та. 86 с.

Возвращаясь на улицу Юности (2009): 40 лет ведущему факультету ВКШ / ред. совет: В. Перепелица (рук. проекта) и др. М. : АИРО-ХХІ. 528 с.

Гайдин, Б. Н. (2011) Вечные образы как константы культуры: тезаурусный анализ «гамлетовского вопроса». Saarbr?cken : Lambert Academic Publishing. 212 c.

Жулковска, Т., Ковалева, А. И., Ауков, В. А. (2003) «Ненормальные» в обществе: Социализация людей с ограниченными интеллектуальными возможностями. М. ; Щецин : ИзА-во Моск. гуманит. ун-та. 432 с.

Захаров, Н. В. (2008) Шекспиризм русской классической литературы: тезаурусный анализ. М. : Изд-во Моск. гуманит. ун-та. 320 с.

Ильинский, И. М. (1986) О состоянии координации научных исследований проблем молодежи и мерах по ее совершенствованию в свете современных требований партии и комсомола // Наука о молодежи - 85 : материалы науч.-практ. конф. М. : ВКШ при ЦК ВАКСМ. С. 38-52.

Ильинский, И. М. (2001) Молодежь и молодежная политика. М. : Голос. 694 с.

Ильинский, И. М. (2002а) Образовательная революция. М. : Изд-во Моск. гуманит.-социальн. академии. 592 с.

Ильинский, И. М. (2002b) XX век: кризис понимания. М. : Изд-во Моск. гуманит.-социальн. академии. $31 \mathrm{c.}$

Ильинский, И. М. (2005) Молодежь как будущее России в категориях войны // Знание. Понимание. Умение. № 3. С. 5-17.

Ильинский, И. М. (2009) Беседы об истории Московского гуманитарного университета. М. : Изд-во Моск. гуманит. ун-та. 328 с.

Ильинский, И. М. (2010) Играющий триумвират: образование, политика, право. М. : Изд-во Моск. гуманит. ун-та. 134 с.

Ильинский, И. М. (2011) Ради себя и «других», ради Будущего (беседа с Вал. А. Ауковым и Н. В. Захаровым) // Знание. Понимание. Умение. № 2. С. 3-32.

Ковалева, А. И. (1997) Социализационная норма в современном российском обществе : автореф. дис. ... А-ра социол. наук. М. 32 с.

Ковалева, А. И. (2017) Общество и личность. М. : Изд-во Моск. гуманит. ун-та. 276 с.

Ковалева, А. И., Богданова, В. В. (2012) Траектория социализации. М. : Изд-во Моск. гуманит. ун-та. $184 \mathrm{c}$.

Ковалева, А. И., Ауков, В. А. (1999) Социология молодежи: Теоретические вопросы. М. : Социум. 351 с.

Ковалева, А. И., Ауков, В. А., Перинская, Н. А. (2016) Социология молодежи: научная школа Московского гуманитарного университета : в 2 ч. Ч. 1. М. : Изд-во Моск. гуманит. ун-та. $442 \mathrm{c.}$ 
Ковалева, А. И., Реут, М. Н. (2001) Социализация неслышашей молодежи. М. : Социум. 222 c.

Кон, И. С. (1967) Социология личности. М. : Политиздат. 383 с.

Костина, А. В. (2008) Тезаурусный подход как новая парадигма гуманитарного знания // Обсерватория культуры. №5. С. 102-109.

Кун, Т. (2001) Структура научных революций : пер. с англ. / сост. В. Ю. Кузнецов. М. : ООО «Издательство АСТ». 608 с.

Аамажаа, Ч. К. (2012) Тезаурусный подход для тувиноведения // Знание. Понимание. Умение. № 2. С. 38-45.

Аосев, А. Ф. (1977) Античная философия истории. М. : Наука. 207 с.

Аебедев, С. А. (2011) Философия науки. Словарь основных терминов. М. : Академический проект. 269 с.

Иуков, В. А. (2006) Ильинский: гуманистическая концепция молодежи // Знание. Понимание. Умение. № 2. С. 48-59.

Иуков, В. А. (2007) И. М. Ильинский о молодежи и молодежной политике // Социально-гуманитарные знания. № 5. С. 158-172.

Ауков, В. А. (2013а) Ильинский Игорь Михайлович о проблемах молодежи и молодежной политики // Youth World Politic. № 2. C. 107-111.

Ауков, В. А. (2013b) Биосоциология молодежи: теоретико-методологические основания. М. : ИзА-во Моск. гуманит. ун-та. 430 с.

Ауков, В. А. (2014) Научная школа Московского гуманитарного университета по социологическим наукам: концепции и исследования молодежи // Научные труды Московского гуманитарного университета. № 10. С. 5-22.

Ауков, В. А. (2017) Разделение наук о природе и наук о культуре в Баденской школе неокантианства и перспективы исследований молодежи (Электронный ресурс)// Горизонты гуманитарного знания. № 5. C. 3-16. URL: http://journals.mosgu.ru/ggz/article/view/597 (дата обращения: 03.08.2019). DOI: 10.17805/ggz.2017.5.1

Ауков, В. А. (2019) Социокультурные основания субъектности российской молодежи (тезаурусная концепция молодежи) : автореф. дис. ... А-ра социол. наук. М. 42 с.

Ауков, В. А., Ауков, Вл. А. (2008) Тезаурусы: Субъектная организация гуманитарного знания. М. : ИзА-во Нац. ин-та бизнеса. 784 с.

Ауков, В. А., Ауков, Вл. А. (2013) Тезаурусы II: Тезаурусный подход к пониманию человека и его мира. М. : Изд-во Нац. ин-та бизнеса. 640 с.

Ауков, В. А., Ауков, Вл. А. (2014) Методология тезаурусного подхода: стратегия понимания // Знание. Понимание. Умение. №1. С. 18-35.

Маркина, Н. А., Твирова, Ю. А., Шумилова, О. Е. (2010) Государственная молодежная политика: мировой и отечественный опыт // Известия Тульского государственного университета. Гуманитарные науки. Вып. 2. Тула : ИзА-во ТулГУ. С. 151-160.

Маркина, Н. А., Твирова, Ю. А., Шумилова, О. Е. (2014) Молодежь и политика // Известия Тульского государственного университета. Гуманитарные науки. Вып. 1. Тула : Изд-во ТулГУ. C. 139-151.

Международные симпозиумы «Приморско» (1970-1985) (1987). София. 318 с.

Молодежь России: воспитание жизнеспособных поколений (1995) : Аоклад Комитета Рос. Федерации по делам молодежи. М. : б. и. 256 с.

Попов, Н. П. (2017) Памяти Ауиса Харриса (1921-2016) // Мониторинг общественного мнения: Экономические и социальные перемены. № 1. С. 299-301.

Уманский, $\Lambda .$, Аутошкин, А. (1984) Психология и педагогика работы комсорга. 3-е изд. М. : Молодая гвардия. 208 с.

Ректор из поколения Победы (2013) / авт.-сост. В. Н. Перепелица. М. : Ауч. 472 с.

Ручкин, Б. А. (2011) Центральная комсомольская школа при ЦК ВАКСМ, Высшая комсомольская школа при ЦК ВАКСМ, Институт молодежи, Московская гуманитарно-социальная 
академия, Московский гуманитарный университет в хронике дат и событий: 1944-2009 годы. М. : ИзА-во Моск. гуманит. ун-та. 86 с.

Селиванова, Н. $\Lambda$. (2018) Как обеспечить успешное развитие научной школы (обращаясь к научной школе $\Lambda$. И. Новиковой) // Отечественная и зарубежная педагогика. Т. 1. № 4 (52). C. $10-22$.

Социология перед судом истории (1995) // Вестник Российской академии наук. Т. 65. № 1. C. 52-64.

Трансдисциплинарность в философской науке: Подходы. Проблемы. Перспективы (2015)/ под ред. В. Бажанова, Р. В. Шольца ; Ин-т философии РАН. М. : Изд. дом «Навигатор. 564 с.

Gross, N. (2006) Comment on Searle // Anthropological Theory. No. 6 (1). P. 45-56. DOI: $10.1177 / 1463499606061734$

Jennings, M. K., Niemi, R. G. (1975) Continuity and Change in Political Orientations: A Longitudinal Study of Two Generations // American Political Science Review. Vol. 69, Issue 4. P. 1316-1335.

Leroux, R. (1998) Histoire et sociologie en France : de l'histoire-science à la sociologie durkheimienne. Paris : PUF. 288 p.

Searle, J. R. (1995) The Construction of Social Reality. N. Y. : Free Press. 256 p.

Searle, J. R. (2010) Making the Social World: The Structure of Human Civilization. N. Y. : Oxford University Press. 224 p.

Yankelovich, D. (1969) Generations apart: a study of the generation gap conducted for CBS News. N. Y. : Columbia. 83 p.

Аата поступления: 05.09.2019 2.

\section{MOSGU SCHOOL OF THOUGHT ON YOUTH STUDIES: ESTABLISHMENT, CONDITION AND PROSPECTS \\ V. A. LUKOV \\ MOSCOW UNIVERSITY FOR THE HUMANITIES}

The paper represents the school of thought of Moscow University for the Humanities on youth studies. The author demonstrates its appearance as the outcome of the rethinking of the earlier youth studies at the establishments preceding the university. During the period of 1987-1991, the research centre was the base for a large scientific project of considerable social and political importance preparation of the bill "General Origins of the State Youth Policy in USSR." This made it possible to develop a conceptual insight into youth, youth movement, and youth policy, which was embodied by I. M. Ilinsky in his humanitarian theory of youth. The theory gave birth to the concepts of "upbringing viable generations", "educational revolution", "socialisation norm”, etc., ensuring the development of the school of thought at the following stages. The combination of the youth problem and thesaurus approach within the MosGU school of thought produced fruitful results.

It is being noted that the school will take on a new quality by an active research into practices initiated in the youth environment by digitisation.

Keywords: school of thought; youth; Moscow University for the Humanities; I. M. Ilinsky's humanitarian theory of youth; Igor Mikhailovich Ilinsky; socialisation; thesaurus approach

\section{REFERENCES}

Basov, N. F., Kirpichnik, A. G. and Rassadin, N. M. (2007) Fenomen pionerfaka (k 45-letiiu istoriko-pedagogicheskogo fakul'teta KGPI). Vestnik Kostromskogo gosudarstvennogo universiteta. Pedagogika. Psikbologiia. Sotsial'naia rabota. Akmeologiia. Iuvenologiia. Sotsiokinetika, no. 1, pp. 97-102. (In Russ.).

Vasil'ev, Iu. A. and Mukhamedzhanov, M. M. (2008) Tsentral' naia komsomol'skaia sbkola : ist. ocherk / head of the research project I. M. Il'inskii ; ed. by A. A. Korolev. Moscow, Izd-vo Mosk. gumanit. un-ta. 86 p. (In Russ.).

Vozvrashchaias' na ulitsu Iunosti (2009): 40 let vedushchemu fakul'tetu VKSh / editorial board V. Perepelitsa et al. Moscow, AIRO-XXI. 528 p. (In Russ.). 
Gaidin, B. N. (2011) Vechnye obrazy kak konstanty kul' tury: tezaurusnyi analiz "gamletovskogo voprosa». Saarbrücken, Lambert Academic Publishing. 212 p. (In Russ.).

Zhulkovska, T., Kovaleva, A. I. and Lukov, V. A. (2003) «Nenormal'nye» v obshchestve: Sotsializatsiia liudei s ogranichennymi intellektual'nymi vozmozhnostiami. Moscow, Shchetsin, Izd-vo Mosk. gumanit. un-ta. 432 p. (In Russ.).

Zakharov, N. V. (2008) Shekspirizm russkoi klassicheskoi literatury: tezaurusnyi analiz. Moscow, Izd-vo Mosk. gumanit. un-ta. 320 p. (In Russ.).

Il'inskii, I. M. (1986) O sostoianii koordinatsii nauchnykh issledovanii problem molodezhi i merakh po ee sovershenstvovaniiu $\mathrm{v}$ svete sovremennykh trebovanii partii i komsomola. In: Nauka o molodezhi - 85 : materialy nauch.-prakt. konf. Moscow, VKSh pri TsK VLKSM. Pp. 38-52. (In Russ.).

Il'inskii, I. M. (2001) Molodezh' i molodezhnaia politika. Moscow, Golos. 694 p. (In Russ.).

Il'inskii, I. M. (2002a) Obrazovatel' naia revoliutsiia. Moscow, Izd-vo Mosk. gumanit.-sotsial'n. akademii. 592 p. (In Russ.).

Il'inskii, I. M. (2002b) XX vek: krizis ponimaniia. Moscow, Izd-vo Mosk. gumanit.-sotsial'n. akademii. 31 p. (In Russ.).

Il'inskii, I. M. (2005) Molodezh' kak budushchee Rossii v kategoriiakh voiny. Znanie. Ponimanie. Umenie, no. 3, pp. 5-17. (In Russ.).

Il'inskii, I. M. (2009) Besedy ob istorii Moskovskogo gumanitarnogo universiteta. Moscow, Izd-vo Mosk. gumanit. un-ta. 328 p. (In Russ.).

Il'inskii, I. M. (2010) Igraiushchii triumvirat: obrazovanie, politika, pravo. Moscow, Izd-vo Mosk. gumanit. un-ta. 134 p. (In Russ.).

Il'inskii, I. M. (2011) Radi sebia i «drugikh», radi Budushchego (beseda s Val. A. Lukovym i N. V. Zakharovym). Znanie. Ponimanie. Umenie, no. 2, pp. 3-32. (In Russ.).

Kovaleva, A. I. (1997) Sotsializatsionnaia norma $v$ sovremennom rossiiskom obshchestve: Theses of Dis. ... Doctor of Sociology. Moscow. 32 p. (In Russ.).

Kovaleva, A. I. (2017) Obshchestvo i lichnost'. Moscow, Izd-vo Mosk. gumanit. un-ta. 276 p. (In Russ.).

Kovaleva, A. I. and Bogdanova, V. V. (2012) Traektoriia sotsializatsii. Moscow, Izd-vo Mosk. gumanit. un-ta. 184 p. (In Russ.).

Kovaleva, A. I. and Lukov, V. A. (1999) Sotsiologiia molodezbi: Teoreticheskie voprosy. Moscow, Sotsium. 351 p. (In Russ.).

Kovaleva, A. I., Lukov, V. A. and Perinskaia, N. A. (2016) Sotsiologiia molodezbi: nauchnaia shkola Moskovskogo gumanitarnogo universiteta : in 2 parts. Moscow, Izd-vo Mosk. gumanit. un-ta. Part 1. 442 p. (In Russ.).

Kovaleva, A. I. and Reut, M. N. (2001) Sotsializatsiia neslyshasbei molodezbi. Moscow, Sotsium. 222 p. (In Russ.).

Kon, I. S. (1967) Sotsiologiia lichnosti. Moscow, Politizdat. 383 p. (In Russ.).

Kostina, A. V. (2008) Tezaurusnyi podkhod kak novaia paradigma gumanitarnogo znaniia. Observatoriia kul'tury, no. 5, pp. 102-109. (In Russ.).

Kun, T. (2001) Struktura nauchnykb revoliutsii : transl. from Engl. / comp. by V. Yu. Kuznetsov. Moscow, OOO «Izdatel'stvo AST». 608 p. (In Russ.).

Lamazhaa, Ch. K. (2012) Tezaurusnyi podkhod dlia tuvinovedeniia. Znanie. Ponimanie. Umenie, no. 2, pp. 38-45. (In Russ.).

Losev, A. F. (1977) Antichnaia filosofiia istorii. Moscow, Nauka. 207 p. (In Russ.).

Lebedev, S. A. (2011) Filosofiia nauki. Slovar' osnovnykb terminov. Moscow, Akademicheskii proekt. 269 p. (In Russ.).

Lukov, V. A. (2006) Il'inskii: gumanisticheskaia kontseptsiia molodezhi. Znanie. Ponimanie. Umenie, no. 2, pp. 48-59. (In Russ.).

Lukov, V. A. (2007) I. M. Il'inskii o molodezhi i molodezhnoi politike. Sotsial'no-gumanitarnye znaniia, no. 5, pp. 158-172. (In Russ.). 
Lukov, V. A. (2013a) Il'inskii Igor' Mikhailovich o problemakh molodezhi i molodezhnoi politiki. Youth World Politic, no. 2, pp. 107-111. (In Russ.).

Lukov, V. A. (2013b) Biosotsiologiia molodezhi: teoretiko-metodologicheskie osnovaniia. Moscow, Izd-vo Mosk. gumanit. un-ta. 430 p. (In Russ.).

Lukov, V. A. (2014) Nauchnaia shkola Moskovskogo gumanitarnogo universiteta po sotsiologicheskim naukam: kontseptsii i issledovaniia molodezhi. Nauchnye trudy Moskovskogo gumanitarnogo universiteta, no. 10, pp. 5-22. (In Russ.).

Lukov, V. A. (2017) Razdelenie nauk o prirode i nauk o kul'ture v Badenskoi shkole neokantianstva i perspektivy issledovanii molodezhi. Gorizonty gumanitarnogo znaniia, no. 5, pp. 3-16 [online] Available at: http://journals.mosgu.ru/ggz/article/view/597 (access date: 03.08.2019). DOI: 10.17805/ggz.2017.5.1 (In Russ.).

Lukov, V. A. (2019) Sotsiokul'turnye osnovaniia sub»ektnosti rossiiskoi molodezhi (tezaurusnaia kontseptsiia molodezhi) : Theses of Dis. ... Doctor of Sociology. Moscow. 42 p. (In Russ.).

Lukov, V. A. and Lukov, Vl. A. (2008) Tezaurusy: Sub'ektnaia organizatsiia gumanitarnogo znaniia. Moscow, Izd-vo Nats. in-ta biznesa. 784 p. (In Russ.).

Lukov, V. A. and Lukov, Vl. A. (2013) Tezaurusy II: Tezaurusnyi podkbod $k$ ponimaniiu cheloveka $i$ ego mira. Moscow, Izd-vo Nats. in-ta biznesa. 640 p. (In Russ.).

Lukov, V. A. and Lukov, Vl. A. (2014) Metodologiia tezaurusnogo podkhoda: strategiia ponimaniia. Znanie. Ponimanie. Umenie, no. 1, pp. 18-35. (In Russ.).

Markina, N. L., Tvirova, Iu. A. and Shumilova, O. E. (2010) Gosudarstvennaia molodezhnaia politika: mirovoi i otechestvennyi opyt. Izvestiia Tul'skogo gosudarstvennogo universiteta. Gumanitarnye nauki, vol. 2, pp. 151-160. (In Russ.).

Markina, N. L., Tvirova, Iu. A. and Shumilova, O. E. (2014) Molodezh' i politika. Izvestiia Tul'skogo gosudarstvennogo universiteta. Gumanitarnye nauki, vol. 1, pp. 139-151. (In Russ.).

Mezhdunarodnye simpoziumy «Primorsko» (1970-1985) (1987). Sofiia. 318 p. (In Russ.).

Molodezh' Rossii: vospitanie zhiznesposobnykb pokolenii (1995) : Doklad Komiteta Ros. Federatsii po delam molodezhi. Moscow, s. n. 256 p. (In Russ.).

Popov, N. P. (2017) Pamiati Luisa Kharrisa (1921-2016). Monitoring obshchestvennogo mneniia: Ekonomicheskie i sotsial'nye peremeny, no. 1, pp. 299-301. (In Russ.).

Umanskii, L. and Lutoshkin, A. (1984) Psikhologiia i pedagogika raboty komsorga. 3nd ed. Moscow, Molodaia gvardiia. 208 p. (In Russ.).

Rektor iz pokoleniia Pobedy (2013) / comp. by V. N. Perepelitsa. Moscow, Luch. 472 p. (In Russ.).

Ruchkin, B. A. (2011) Tsentral' naia komsomol'skaia shkola pri TsK VLKSM, Vysshaia komsomol' skaia shkola pri TsK VLKSM, Institut molodezbi, Moskovskaia gumanitarno-sotsial' naia akademiia, Moskovskii gumanitarnyi universitet v kbronike dat i sobytii: 1944-2009 gody. Moscow, Izd-vo Mosk. gumanit. un-ta. 86 p. (In Russ.).

Selivanova, N. L. (2018) Kak obespechit' uspeshnoe razvitie nauchnoi shkoly (obrashchaias' k nauchnoi shkole L. I. Novikovoi). Otechestvennaia i zarubezhnaia pedagogika, vol. 1, no. 4 (52), pp. 10-22. (In Russ.).

Sotsiologiia pered sudom istorii (1995). Vestnik Rossiiskoi akademii nauk, vol. 65, no. 1, pp. 52-64.

Transdistsiplinarnost' $v$ filosofskoi nauke: Podkbody. Problemy. Perspektivy (2015) / ed. by V. Bazhanova and R. V. Shol'tsa. Moscow, Izd. dom "Navigator”. 564 p. (In Russ.).

Gross, N. (2006) Comment on Searle. Anthropological Theory, no. 6 (1), pp. 45-56. DOI: $10.1177 / 1463499606061734$

Jennings, M. K. and Niemi, R. G. (1975) Continuity and Change in Political Orientations: A Longitudinal Study of Two Generations. American Political Science Review, vol. 69, issue 4, pp. 1316-1335.

Leroux, R. (1998) Histoire et sociologie en France : de l'bistoire-science á la sociologie durkbeimienne. Paris, PUF. 288 p.

Searle, J. R. (1995) The Construction of Social Reality. N. Y., Free Press. 256 p. 
Searle, J. R. (2010) Making the Social World: The Structure of Human Civilization. N. Y., Oxford University Press. 224 p.

Yankelovich, D. (1969) Generations apart: a study of the generation gap conducted for CBS News. N. Y., Columbia. 83 p.

Submission date: 05.09.2019.

Ауков Валерий Андреевич - доктор философских наук, профессор, директор Центра социального проектирования и тезаурусных концепций Института фундаментальных и прикладных исследований Московского гуманитарного университета, заслуженный деятель науки Российской Федерации. Академик Международной академии наук (IAS). Адрес: 111395, Россия, г. Москва, ул. Юности, д. 5. Тел.: +7 (499) 374-75-95. Эл. адрес: v-lukov@list.ru

Lukov Valeriy Andreyevich, Doctor of Philosophy, Professor, Director, Centre for Social Planning and Thesaurus Conceptions, Institute of Fundamental and Applied Studies, Moscow University for the Humanities; Honoured Scientist of the Russian Federation, Member, International Academy of Sciences. Postal address: 5, Yunosti St., Moscow, Russian Federation, 111395. Tel.: +7 (499) 374-75-95. E-mail: v-lukov@list.ru 